\title{
Research Progress of Neonatal Acute Respiratory Distress Syndrome
}

\author{
Huo Mengyue, Mei Hua* and Liu Chunzhi \\ Division of Neonatology, Department of Pediatrics, China \\ *Corresponding author: Mei Hua, Division of Neonatology, Department of Pediatrics, China
}

\begin{abstract}
ARTICLE INFO
Received: 幽 November 04, 2019

Published: November 14, 2019

Citation: Huo Mengyue, Mei Hua, Liu Chunzhi. Research Progress of Neonatal Acute Respiratory Distress Syndrome. Biomed J Sci \& Tech Res 22(5)-2019. BJSTR. MS.ID.003820.

ABSTRACT

Neonatal Acute Respiratory Distress Syndrome (ARDS) is one of the most common critical diseases in neonatal period. In recent years, with the rapid development of perinatal medicine, the survival rate of children with ARDS has increased significantly, but the mortality rate is still high. At present, there is no specific treatment for the disease, mainly according to its pathophysiological changes to take comprehensive symptomatic treatment measures, including respiratory support, extracorporeal membrane oxygenation therapy, PS replacement, nutritional support and liquid management. In this paper, the diagnostic criteria, pathogenesis and treatment strategies of neonatal ARDS were reviewed in order to provide some theoretical basis for the diagnosis and treatment of neonatal ARDS in the future.
\end{abstract}

Keywords: Acute Respiratory Distress Syndrome; Neonat; Newbor; Diagnosis; Pathophysiology; Treatments

\section{Introduction}

Acute respiratory distress syndrome (ARDS) is one of the most common respiratory acute and critical diseases in newborns. It refers to the acute inflammatory reaction of the lung caused by various pathogenic factors inside and outside the lung. It is characterized by progressive dyspnea, intractable hypoxia and decreased lung compliance [1]. With the vigorous development of neonatal intensive care unit, the survival rate of newborns, especially premature infants, has increased year by year, and the incidence of ARDS has also increased significantly, but the mortality rate is still high [2]. In view of the fact that the treatment of neonatal ARDS is only limited to the comprehensive treatment based on the corresponding respiratory support therapy, it is the focus of every neonatal pediatrician to understand the pathogenesis and diagnostic criteria of ARDS and actively take reasonable treatment measures.

\section{Evolution of Ards Definition}

Since Ashbaugh et al [3] first put forward the concept of ARDS in the 1960s, pediatricians have realized that children's ARDS is different from adult ARDS. The 1994 American-European Consensus Conference(AECC) defined Acute Lung Injury (ALI) as $\mathrm{PaO}_{2} / \mathrm{FiO}_{2} \leq 300 \mathrm{mmHg}$, ARDS as $\mathrm{PaO}_{2} / \mathrm{Fio}_{2} \leq 200 \mathrm{mmHg}$, and later referred to "Acute" as the double meaning of "acute" rather than "adult or acute", in order to accurately reflect the fact that this syndrome can occur in both adults and children, the diagnostic criteria of ARDS have been widely used in adults and children [4]. In 2012, the European Critical Care Association presided over the revision of the new diagnostic criteria for ARDS in Berlin, Germany. The Berlin definition addresses many of the limitations of the definition of AECC and believes that ARDS is a unique pathophysiological process. It can be described by time, imaging changes and severity, and ARDS can be divided into mild, moderate and severe according to $\mathrm{PaO}_{2} / \mathrm{Fio}_{2}$ ratio [5]. This was followed by a multicenter clinical study conducted by the European Society of Pedatric and Neonatal Intensive Care (ESPNIC) to verify the effectiveness of the Berlin standard in children aged 1 to 18 months [6]. According to the AECC and the Berlin definition, Barreira et al. [7] conducted a multicenter study of children aged from 1 month to 15 years in PICU. The results showed that the mortality rate and ventilator use days of children with severe ARDS were significantly higher than those with mild to moderate ARDS. It is considered that compared with the definition of AECC, the Berlin definition is more effective in predicting mortality and leaving ventilator and can better distinguish the severity of ARDS in children. 
Although the definitions of AECC and Berlin are the perfection and expansion of the diagnostic criteria of ARDS, neither of them clearly puts forward the diagnostic criteria of ARDS in children and newborns, and has some limitations in the application of ARDS in children, such as the determination of $\mathrm{PaO}_{2}$ and the calculation of $\mathrm{PaO}_{2} / \mathrm{FiO}_{2}$ ratio. The two definitions did not take into account the etiology, risk factors and pathophysiological differences between adults and children with ARDS. In view of the fact that there is still no specific definition and corresponding clinical trials of ARDS in children, the Paediatric Acute Lung Injury Consensus Conference
[8] (PALICC) proposed the definition and classification of Pediatric Acute Respiratory Distress Syndrome (pARDS) for the first time. To clarify the pathogenic factors, etiology and pathophysiology, put forward suggestions for treatment, and determine the focus of research. The PALICC standard states that pARDS includes children of all ages from newborn to adolescence and is unique in pathophysiology, etiology and high-risk factors [9]. PALICC standard not only reduces the mortality of ARDS in children and adults, but also provides a strong guarantee for improving the quality of life of patients [10].

Table 1: Diagnostic criteria of neonatal Acute Respiratory Distress Syndrome (ARDS).

\begin{tabular}{|c|c|c|c|c|c|c|c|c|c|c|c|c|}
\hline & AECC criteria & \multicolumn{3}{|c|}{ Berlin criteria } & \multicolumn{4}{|c|}{ PALICCcriteria } & \multicolumn{4}{|c|}{ Montreux criteria } \\
\hline Timing & Acute onset & \multicolumn{3}{|c|}{$\begin{array}{c}\text { Within } 1 \text { week of known clinical } \\
\text { insult or new or worsening respira- } \\
\text { tory symptoms }\end{array}$} & \multicolumn{4}{|c|}{ Within 7 days of known clinical insult } & \multicolumn{4}{|c|}{$\begin{array}{l}\text { Acute onset (ie, within one week) } \\
\text { from a known or suspected clin- } \\
\text { ical insult }\end{array}$} \\
\hline \multirow[t]{2}{*}{ Age } & \multirow[t]{2}{*}{ None } & \multirow{2}{*}{\multicolumn{3}{|c|}{ None }} & \multirow{2}{*}{\multicolumn{4}{|c|}{ Exclude patients with peri-natal related lung disease }} & \multicolumn{2}{|c|}{$\begin{array}{l}\text { born within } \\
40 \text { weeks of } \\
\text { pregnancy } \\
\text { (including } \\
\text { premature } \\
\text { infants) }\end{array}$} & \multicolumn{2}{|c|}{$\begin{array}{l}\text { neonate born } \\
\text { after } 40 \text { weeks of } \\
\text { pregnancy }\end{array}$} \\
\hline & & & & & & & & & \multicolumn{2}{|c|}{$\begin{array}{l}44 \text { weeks from } \\
\text { birth to gesta- } \\
\text { tional age }\end{array}$} & \multicolumn{2}{|r|}{$\begin{array}{l}\text { from birth to } \\
4 \text { weeks after } \\
\text { birth }\end{array}$} \\
\hline $\begin{array}{l}\text { Chest } \\
\text { Imaging }\end{array}$ & $\begin{array}{l}\text { Bilateral infil- } \\
\text { trates observed } \\
\text { on frontal chest } \\
\text { radiograph }\end{array}$ & \multicolumn{3}{|c|}{$\begin{array}{c}\text { Bilateral opacities-not fully explained } \\
\text { by effusions, lobar/lung collapse, or } \\
\text { nodules }\end{array}$} & \multicolumn{4}{|c|}{$\begin{array}{l}\text { Chest imaging findings of new infiltrate(s) consistent } \\
\text { with acute pulmonary parenchymal disease }\end{array}$} & \multicolumn{4}{|c|}{$\begin{array}{l}\text { Diffuse, bilateral, and irregular } \\
\text { opacities or infiltrates, or complete } \\
\text { opacification of the lungs, which } \\
\text { are not fully explained by local } \\
\text { effusions, atelectasis, RDS, TTN, } \\
\text { orcongenital anomalies }\end{array}$} \\
\hline $\begin{array}{l}\text { Causes } \\
\text { of pul- } \\
\text { monary } \\
\text { edema }\end{array}$ & $\begin{array}{l}\text { PAWP } \leq 18 \\
\text { mmHg when } \\
\text { measured or } \\
\text { no clinical } \\
\text { evidence of left } \\
\text { atrial hyper- } \\
\text { tension }\end{array}$ & \multicolumn{3}{|c|}{$\begin{array}{l}\text { Respiratory failure not fully explained } \\
\text { by cardiac failure or fluid overload } \\
\text { Need objective assessment (eg, echo- } \\
\text { cardiography) to exclude hydrostatic } \\
\text { dema if no risk factor present }\end{array}$} & Respirator & $\begin{array}{l}\text { failure not fu } \\
\text { or flu }\end{array}$ & $\begin{array}{l}\text { explained by ca } \\
\text { verload }\end{array}$ & ac failure & \multicolumn{4}{|c|}{$\begin{array}{l}\text { Absence of congenital heart dis- } \\
\text { ease explaining the oedema (this } \\
\text { includes ductus arteriosus with } \\
\text { pulmonary overflow if no acute } \\
\text { pulmonary haemorrhage exists). } \\
\text { Echocardiography is needed to } \\
\text { verify the origin of oedema }\end{array}$} \\
\hline \multirow{4}{*}{$\begin{array}{l}\text { Oxygen- } \\
\text { ation }\end{array}$} & $\begin{array}{l}\text { ARDS: } \mathrm{PaO}_{2} \\
/ \mathrm{Fio}_{2} \leq 200 \\
\mathrm{mmHg} \text { (regard- } \\
\text { less of PEEP) }\end{array}$ & Mild & $\begin{array}{l}\text { Moder- } \\
\text { ate }\end{array}$ & Severe & $\begin{array}{l}\text { Non-Inva- } \\
\text { sive me- } \\
\text { chanical } \\
\text { ventilation }\end{array}$ & Invasi & nechanical ven & tion & \multirow{2}{*}{ Mild } & \multirow{2}{*}{\multicolumn{2}{|c|}{$\begin{array}{l}\text { Moder- } \\
\text { ate }\end{array}$}} & \multirow{2}{*}{ Severe } \\
\hline & & \multirow{3}{*}{$\begin{array}{l}200 \\
\mathrm{mmHg}< \\
\quad \mathrm{PaO}_{2} / \\
\mathrm{Fio}_{2} \leq 300 \\
\text { mmHg } \\
\text { with PEEP } \\
\text { or CPAP } \\
\geq 5 \mathrm{~cm} \mathrm{H}_{2} \mathrm{O}\end{array}$} & \multirow{3}{*}{$\begin{array}{c}100 \\
\mathrm{mmHg} \\
<\mathrm{PaO}_{2} \\
/ \mathrm{Fio}_{2} \\
\leq 200 \\
\mathrm{mmHg} \\
\text { with } \\
\mathrm{PEEP} \\
\geq 5 \mathrm{~cm} \\
\mathrm{H}_{2} \mathrm{O}\end{array}$} & \multirow{3}{*}{$\begin{array}{l}\mathrm{PaO}_{2} / \mathrm{FiO}_{2} \\
\leq 100 \mathrm{mmHg} \\
\text { with PEEP } \geq 5 \\
\quad \mathrm{~cm} \mathrm{H}_{2} \mathrm{O}\end{array}$} & \multirow{3}{*}{$\begin{array}{c}\text { PARDS } \\
\text { (No sever- } \\
\text { ity strat- } \\
\text { ification) } \\
\text { Full } \\
\text { face-mask } \\
\text { bi-level } \\
\text { ventilation } \\
\text { or } \mathrm{CPAP} \geq \mathrm{c} \\
m \mathrm{H}_{2} \mathrm{O} \\
\mathrm{PF} \\
\text { ratio } \leq 300 \\
\mathrm{SFra}- \\
\text { tio } \leq 264\end{array}$} & Mild & Moderate & Severe & & & & \\
\hline & $\begin{array}{l}\text { ALI: } \mathrm{PaO}_{2} / \mathrm{Fio}_{2} \\
\leq 300 \mathrm{mmHg} \\
\text { (regardless of } \\
\text { PEEP) }\end{array}$ & & & & & $4 \leq 0 \mathrm{I}<8$ & $8 \leq 0 \mathrm{I}<16$ & $\mathrm{OI} \geq 16$ & \multirow[t]{2}{*}{$4 \leq 0 \mathrm{I}<8$} & \multirow{2}{*}{\multicolumn{2}{|c|}{$8 \leq 0 \mathrm{I}<16$}} & \multirow[t]{2}{*}{$\mathrm{OI} \geq 16$} \\
\hline & & & & & & $5 \leq 0 \mathrm{OSI}<7.5$ & $7.5 \leq 0 \mathrm{OSI}<12.3$ & OSI $\geq 12.3$ & & & & \\
\hline
\end{tabular}

PEEP: positive end-expiratory pressure; $\mathrm{Pao}_{2}$ : arterial oxygen tension; $\mathrm{Fio}_{2}$ : inspiratory oxygen fraction; $\mathrm{SpO}_{2}$ : arterial oxygen saturation measured by pulse oximetry; CT: computed tomography $\mathrm{OI}=$ oxygenation index, $\mathrm{OSI}=$ oxygen saturation index. $\mathrm{OI}=($ $\mathrm{Fio}_{2} \times$ mean airway pressure $\left.\times 100\right) / \mathrm{Pao}_{2} . \mathrm{OSI}=\left(\mathrm{Fio}_{2} \times\right.$ mean airway pressure $\left.\times 100\right) / \mathrm{Spo}_{2} \mathrm{TTN}=$ transienttachypnoea ofthe neona. 
Although the PALICC standard has achieved a major breakthrough in the age of the ARDS standard, it specifically excludes Perinatal specific diseases such as acute hypoxia in newborns and secondary severe lung injuries such as meconium aspiration syndrome and congenital disseminated pneumonia. The clinical characteristics of neonatal ARDS have not been pointed out [11]. On the basis of the existing research on ARDS, the international multi-center and multi-disciplinary assistance group established the diagnostic criteria of neonatal ARDS for the first time in 2017, that is, the Montreux criteria [12]. At present, the Montreux criteria is the first ARDS diagnostic standard for newborns in the world. It is consistent with the diagnostic criteria of ARDS in children and adults as far as possible. It not only emphasizes the diagnostic criteria, exclusion criteria and imaging examinations that need to be met. The applicable age of neonatal ARDS, the standard of oxygenation disorder and the threshold of oxygenation index to distinguish mild, moderate and severe were also clarified. Montreux criteria is the expansion and perfection of ARDS consensus guide for children (PALICC standard). It plays a positive role in the diagnosis and treatment of critical newborns (Table 1).

\section{Pathogensis of Ards}

Although the pathogenesis of ARDS has not been fully understood, current studies have shown that systemic inflammation is a key link in the occurrence and development of ARDS, severe inflammation leads to changes in vascular permeability, resulting in acute pulmonary edema [13-15]. After primary injuries such as infection, trauma and chemical factors affect alveolar epithelial cells and vascular endothelial cells, the boundary between alveolar epithelial cells and vascular endothelial cells is destroyed, and pulmonary capillary barrier dysfunction leads to increased permeability. Promote inflammatory cells to enter the alveolar cavity and pulmonary capillaries, protein-rich liquid quickly enter the lung tissue to cause acute pulmonary edema [16-17]. The results showed that the activity of type II secretory phospholipase A2 (sPLA2) was increased in both adults and children with ARDS. SPLA2 could promote inflammation and decompose surfactant phospholipids directly by hydrolyzing Dipalm Oil-Phosphate Diol-Cholinesterase (DDPC). At the same time, oxidative hydrolysis activated by inflammatory reaction can increase the degradation of PS, both of which can cause secondary deficiency of PS, resulting in hyaline membrane formation and alveolar collapse [18]. Therefore, pulmonary inflammation caused by inflammatory diseases, which leads to abnormal PS, is an important reason for the occurrence of ARDS.

Neonatal period is a unique stage which is different from adults and children. It not only has high mortality, but also has particularity in the inducement and pathological characteristics of ARDS. Neonatal ARDS can be triggered by direct injury of the lung parenchyma (that is, direct or primary ARDS), such as Meconium Aspiration Syndrome (MAS), pneumonia, or extrapulmonary processes (that is, indirect or secondary ARDS), such as septicemia, necrotizing enterocolitis, Perinatal asphyxia and so on. In addition, some studies have found that the incidence of neonatal ARDS is also related to preterm delivery, caesarean section, diabetic mother, placenta previa and acidosis. It can be seen that the pathogenesis of neonatal ARDS is complex. How to treat ARDS from the aspect of pathophysiology is worthy of more in-depth study (Figure 1).

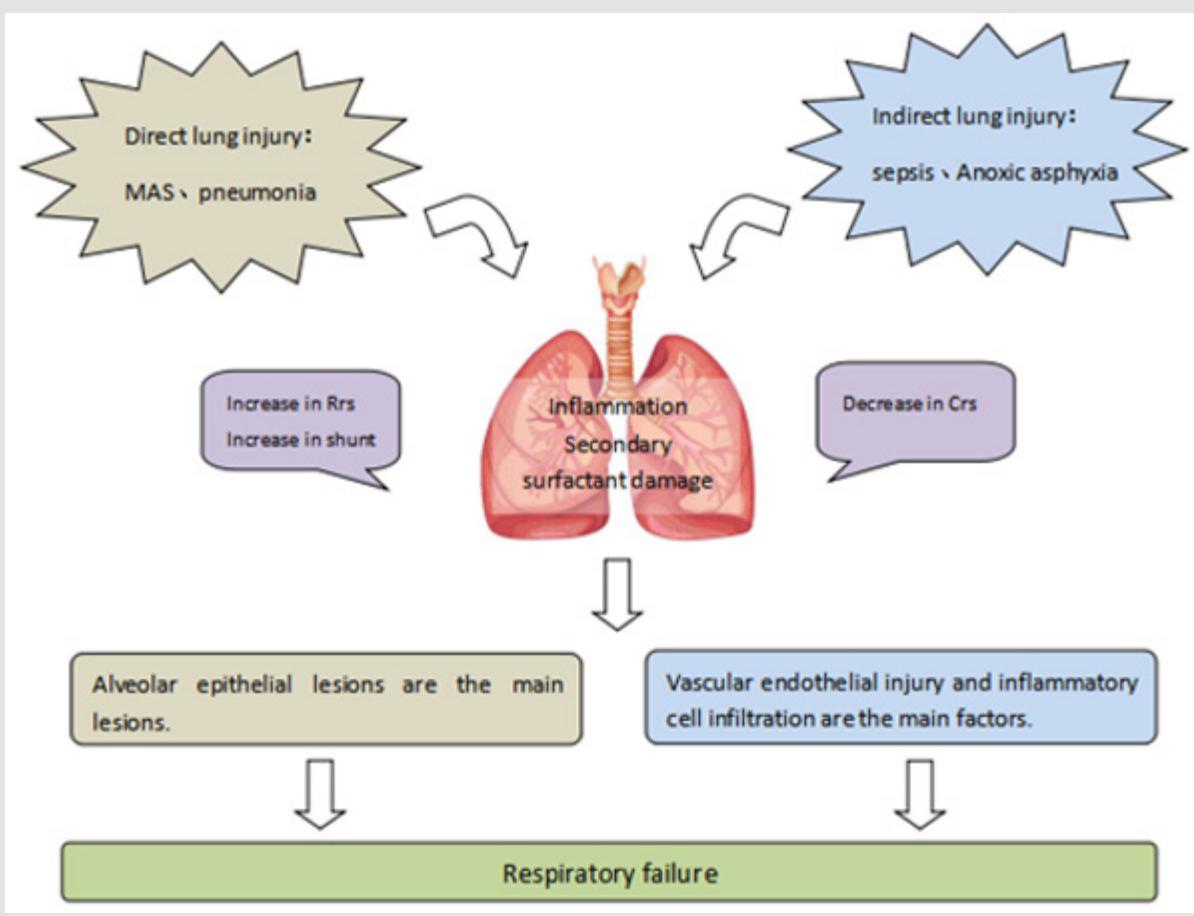

Figure 1: Pathophysiological mechanism of neonatal Acute Respiratory Distress Syndrome (ARDS)

Crs=respiratory system compliance. Rrs=respiratory system resistance. 


\section{Prevention and Treatment of Ards}

At present, there are no effective treatment measures for neonatal ARDS, the main treatment methods include respiratory support, PS replacement, extracorporeal membrane oxygenation therapy, nutritional support and liquid management. How to treat ARDS is the key issue of current research.

\section{Treatment of Primary Diseases}

A variety of internal and external factors such as meconium aspiration syndrome, pneumonia, perinatal asphyxia, septicemia, neonatal necrotizing enterocolitis and so on can cause neonatal ARDS. Therefore, it is the primary task of prevention and treatment of ARDS to take corresponding treatment measures for the primary disease in the early stage and curb the systemic uncontrolled inflammatory reaction induced by it.

\section{Respiratory Support}

Mechanical Ventilation (MV) is an important treatment for ARDS, but inappropriate mechanical ventilation can cause lung injury in children [19-20]. The lung pathology of children with ARDS is characterized by inflammation, partial atelectasis and normal alveoli at the same time. Therefore, in this case, if the traditional mechanical ventilation mode of continuous application of climax volume and inappropriate end-tidal pressure is used, at the same time of opening the collapsed alveoli, the normal alveoli were overexpanded, resulting in normal alveolar injury, that is, ventilator-induced lung injury (ventilator induced lung injure,VILI) [21-22]. Air pressure injury, volume injury, lung injury caused by alveolar overexpansion and atelectasis after low lung volume ventilation were all related to VILI. In order to avoid pulmonary overexpansion and pulmonary wilting injury, it is recommended to use Pulmonary Protective Ventilation Strategy (PLVS), that is, low tidal volume and appropriate PEEP to reduce lung volume injury and lung collapse injury as much as possible [23-24]. A large sample randomized controlled trial in the United States confirmed that low tidal volume and limited platform pressure can reduce the mortality of ARDS [25].

Although PLVS is a major breakthrough in the treatment of ARDS, the latest report points out that the alveoli are still overinflated when PLVS is used, and patients are still at risk of developing VILI. The lower the tidal volume and platform pressure, the more beneficial to the patients. Therefore, some scholars have proposed the concept of Ultra-Protective Lung Ventilation Strategy (UPLVS), that is, it is suggested that the tidal volume should be changed from $6 \mathrm{ml} / \mathrm{kg}$ to $4 \mathrm{ml} / \mathrm{kg}$, and the platform pressure should be changed from $30 \mathrm{mmH}_{2} \mathrm{O}$ to $25 \mathrm{mmH}_{2} \mathrm{O}$ [26-27]. Although lower tidal volume and lower platform pressure in UPLVS can improve the rate of ARDS patients, it can increase the risk of respiratory acidosis, high respiratory rate ventilation and high PEEP ventilation [28]. Both PLVS and UPLVS use lower tidal volume to reduce pulmonary overexpansion but ignore the simultaneous alveolar collapse in children with ARDS. In order to solve this problem, some scholars suggest that intermittent administration of pressure higher than conventional breath pressure during mechanical ventilation and maintaining it for a period of time can not only restore collapsed alveoli, but also prevent repeated alveolar dilatation and collapse, that is, Lung Recruitment Maneuver (LRM) [29-31]. However, at present, this strategy is rarely used in newborns, and large sample multicenter studies are rare, so the method and effectiveness of LRM in neonatal ARDS remains to be further confirmed by clinicians.

In view of the fact that invasive ventilation can lead to ventilatorassociated pneumonia and other complications, some scholars have proposed that it is a positive pressure ventilation support technique without endotracheal intubation, that is, Non-Invasive Positive Pressure Ventilation (NIPPV) [32]. At present, a number of studies have confirmed the effectiveness and safety of NIPPV as a first-line treatment to avoid endotracheal intubation in patients with ALI/ARDS [33-36]. The consensus meeting on Acute Lung injury in Children recommended that children with ARDS should use NIPPV, and PEEP noninvasive ventilation at an early stage of the disease [8]. Recent studies have shown that NIPPV can also be used for the transitional treatment of ventilator and extubation in children with ARDS, so further exploring the prospect of NIPPV in the treatment of ARDS has been the focus of pediatricians.

High Frequency Oscillatory Ventilation (HFOV) is a new mechanical ventilation mode developed in recent years. HFOV uses hyperphysiological ventilation frequency concussion to maintain bi-directional pressure, and the ventilation frequency is 4 times higher than the normal frequency. Gas exchange at low tidal volume and constant airway pressure can not only improve oxygenation and efficient clearance of $\mathrm{Co}_{2}$, but also avoid complications such as lung injury caused by overexpansion of the lungs. It is the most advanced high frequency ventilation technology at present [37-40]. Many studies at home and abroad have shown that although HFOV cannot reduce the mortality of children with ARDS, compared with Conventional Mechanical Ventilation (CMV), HFOV can significantly improve oxygenation [41-42]. The latest guidelines recommend that in the absence of clinical evidence of decreased chest wall compliance, HFOV is considered an alternative ventilation mode in patients with moderate and severe ARDS whose respiratory plateau pressure exceeds $28 \mathrm{cmH}_{2} \mathrm{O}$. It is suggested that the oxygenation, $\mathrm{Co}_{2}$ response and hemodynamic variables should be continuously monitored in HFOV to explore the potential of lung retension by gradually increasing and reducing continuous dilatation pressure, so as to obtain the best lung volume. However, High-Frequency Jet Ventilation (HFJV) and High-Frequency Percussive Ventilation (HFPV) are not recommended in children with ARDS [8].

Prone position ventilation is a commonly used non-mechanical ventilation method for neonatal ARDS. One of the common pathological changes in children with ARDS is the decrease of lung volume, which is mainly characterized by less functional residual 
volume. The principle of prone ventilation in the treatment of ARDS is to take the prone position during ventilation, to reduce the compression of the heart to the lungs and to improve the oxygenation function of the patients by increasing the functional residual volume. And reduce the incidence of adverse reactions such as lung injury and oxygen poisoning [43-45]. Many studies have shown that prone ventilation can reduce the mortality of patients with ARDS. Therefore, when traditional mechanical ventilation cannot improve the oxygenation index, the early use of prone ventilation should be considered in time and at least for 10 hours [46-47]. Although prone position ventilation can improve oxygenation and has no effect on hemodynamics, there is still no unified standard for when to use prone position ventilation and duration in newborn children with ARDS, which needs to be further studied in clinical practice.

\section{In Vitro Life Support Technology}

In recent years, with the gradual increase in the incidence of refractory ARDS, the application of Extracorporeal Membrane Oxygenation (ECMO) in ARDS has gradually increased. At present, about 3000 children worldwide receive ECMO treatment each year [48-49]. ECMO mainly improves oxygenation and carbon dioxide removal through cardiopulmonary bypass, thus partially or completely replacing cardiopulmonary function to maintain blood supply and oxygen supply to major organs, which can not only buy time for pulmonary function recovery, it can also reduce the risk of ventilator-associated lung injury and improve hypoxia. Therefore, ECMO is the most advanced support technology at present, and it has become the only effective treatment for children with ARDS when conventional treatment is ineffective [50-55]. A cohort study of multicenter randomized controlled data in the United States showed that children treated with ECMO did not have a better prognosis than children with severe ARDS who did not receive ECMO support [56]. Therefore, how to accurately grasp the indications of the application of ECOM still needs a strictly implemented randomized controlled clinical trial to provide a clear answer to this long-term problem.

\section{Ps Replacement Therapy}

Pulmonary Surfactant (PS) is a phospholipid formed and stored by type II alveolar epithelial cells. It can not only reduce alveolar surface tension to prevent alveolar collapse at the end of breath, but also increase pulmonary compliance. At the same time, it also has anti-inflammatory and antibacterial effects [57-59]. Because most newborns have primary or secondary PS deficiency in ARDS, the mortality of neonatal ARDS has been reduced by $50 \%$ since the emergence of exogenous PS replacement therapy [60]. The results of Wang LP et al. [61] showed that early application of PS combined with mechanical ventilation could significantly improve pulmonary oxygenation and compliance and inhibit inflammation in children with ARDS. A multicenter randomized controlled trial confirmed that intratracheal infusion of PS not only improved oxygenation in patients with ARDS, but also significantly reduced mortality [4]. And studies have shown that improvements in surfactant occur only in patients with direct lung injury (pneumonia, inhalation or near drowning). To verify this conclusion, Willson et al. [62] conducted a multicenter randomized controlled study in 6 different countries in children with ALI/ARDS caused by direct lung injury. The results showed that intratracheal infusion of PS did not improve oxygenation. Therefore, exogenous PS is not recommended for children with ALI/ARDS. Therefore, the optimal use time, dosage and curative effect of PS in neonatal ARDS still need to be further explored.

\section{Nutritional Support and Liquid Management}

For children with ARDS, nutrition supply is not only the provision of energy, appropriate nutrition supply can prevent heat consumption, correct malnutrition, shorten the time of mechanical ventilation, regulate immune function and improve oxygenation in order to improve the prognosis of patients with ARDS [63-64]. Therefore, nutritional support as an important means of ARDS treatment has been widely used in clinical practice. A multicenter study of 500 children with PICU showed that children who ate more than 66 percent of the prescribed calories had a significantly lower mortality rate than those who received less than 33 percent of the prescribed calories [65]. Further studies by Wong JJ et al. [66] have shown that consuming enough protein can improve clinical outcomes better than eating enough calories. Neonatal nutritional support includes enteral nutrition and parenteral nutrition. A small amount of enteral nutrition combined with most parenteral nutrition is beneficial to the establishment of intestinal flora, maintain intestinal function and reduce intestinal complications. A randomized controlled trial shows that early rational use of enteral nutrition support can not only improve the clinical efficacy of ARDS patients, reduce the incidence of infection, help to control blood glucose, improve lung function. It can also shorten the time of mechanical ventilation and ICU hospitalization and reduce the hospitalization cost [67].

The main pathological features of neonatal ARDS are noncardiogenic pulmonary edema, which can affect respiratory function through the following aspects: decrease of pulmonary compliance to increase respiratory work, increase of intrapulmonary shunt resulting in hypoxia, and aggravation of pulmonary hypertension. Combined mechanical ventilation can promote the occurrence of pulmonary inflammation and reduce the secretion of PS, thus aggravating the damage of pulmonary capillary barrier. Therefore, through liquid management to reduce the production of pulmonary edema fluid and promote the discharge of edema fluid is an important link in the treatment of ARDS. The goal of fluid therapy in critically ill children with ARDS is to ensure adequate end organ perfusion. A number of studies have confirmed that early fluid overload can aggravate the clinical outcome of children with ARDS [68-71]. The results of a Meta-analysis showed that strict fluid management strategy in adults and children with ARDS could 
reduce the days of ventilator use and shorten the length of hospital stay [72]. At present, liquid overload management mainly includes non-invasive strategies such as diuretics and fluid restriction and invasive methods such as Continuous Renal Replacement Therapy (CRRT). Studies have shown that patients who start using CRRT earlier may have better clinical results [73]. On the premise of ensuring hemodynamic stability and perfusion of tissues and organs, restricted fluid management is helpful to improve the oxygenation and lung injury in patients with ARDS, but whether it can reduce the mortality of patients with ARDS remains to be further confirmed.

\section{Other Treatment}

Ambroxol hydrochloride not only has the characteristics of promoting mucus excretion and dissolving secretions, but also has antioxidant and anti-inflammatory effects, and can promote the production of pulmonary surfactant [74]. A Meta-analysis showed that $\mathrm{PaO}_{2} / \mathrm{Fio}_{2}, \mathrm{PaO}_{2}$ and $\mathrm{SaO}_{2}$ increased only 7 days after high dose ambroxol ( $>15 \mathrm{mg} / \mathrm{kg}$ or $1000 \mathrm{mg} / \mathrm{d}$ ) treatment in patients with ALI/ARDS, which may be related to the antioxidant and antiinflammatory properties of ambroxol [75]. Inhaled nitric oxide (iNO) in the treatment of ARDS is one of the most widely studied interventions in the past two decades. Although iNO treatment can improve oxygenation, there is still no study to prove whether there is a decrease in mortality [76]. A study of 161 children with ARDS showed that inhaling carbon monoxide could reduce the duration of mechanical ventilation, but there was no significant difference in mortality between the two groups [77]. Therefore, at present, iNO is not recommended for routine use in patients with ARDS, but it can be used in the rescue treatment of patients with severe intractable hypoxia [78]. Other treatments, such as liquid ventilation, volume target ventilation, Mesenchymal Stem Cell (MSC) and so on, still need further research and clinical trials to confirm [79-80].

\section{Conclusion}

Although great progress has been made in antenatal prevention and postnatal treatment of neonatal ARDS in recent years, there is still no single treatment that can significantly improve the survival of newborns. In view of the high mortality of neonatal ARDS and its specificity in etiology, pathophysiology and so on, the large sample multicenter prospective study on neonatal ARDS diagnosis and treatment is worth looking forward to.

\section{Acknowledgment}

H-MY M-H L-CZ has made contributions to the research, design, revision and finalization of manuscripts.

\section{References}

1. Maria A, Agarwal S, Sharma A (2017) Acute respiratory distress syndrome in a neonate due to possible transfusion-related acute lung injury. Asian J Transfus Sci 11(2): 203-205.

2. Troiani S, Cardona A, Milioni M, Monacelli D, Verrotti A, et al. (2017) Evidence of impaired microvascular dilatation in preterms with acute respiratory distress syndrome. Int J Cardiol 241: 83-86.
3. Ashbaugh DG, Bigelow DB, Petty TL, Levine BE (1967) Acute respiratory distress in adults. Lancet 2(7511): 319-323.

4. Amigoni A, Pettenazzo A, Stritoni V, Circelli M (2017) Surfactants in Acute Respiratory Distress Syndrome in Infants and Children: Past, Present and Future. Clin Drug Investig 37(8): 729-736.

5. ARDS Definition Task Force, Ranieri VM, Rubenfeld GD, Thompson BT, Ferguson ND, et al. (2012) Acute respiratory distress syndrome: The Berlin Definition. JAMA 307(23): 2526-2533.

6. Hermon M, Dotzler S, Brandt JB, Strohmaier W, Golej J (2019) Extended use of the modified Berlin Definition based on age-related subgroup analysis inpediatric ARDS. Wien Med Wochenschr 169(3-4): 93-98.

7. Barreira ER, Munoz GO, Cavalheiro PO, Suzuki A, Degaspare N, et al. (2015) Epidemiology and outcomes of acute respiratory distress syndrome in children according to theBerlin definition: A multicenter prospective study. Crit Care Med 43(5): 947-953.

8. (2015) Pediatric Acute Lung Injury Consensus Conference Group. Pediatric acute respiratory distress syndrome : Consensus recommendations from the Pediatric Acute Lung Injury Consensus Conference. Pediatr Crit Care Med 16(5): 428-439.

9. Rotta AT, Piva JP, Andreolio C, de Carvalho WB, Garcia PC R (2015) Progress and perspectives in pediatric acute respiratory distress syndrome. Rev Bras Ter Intensiva 27(3): 266-273.

10. Parvathaneni K, Belani S, Leung D, Newth CJ, Khemani RG (2017) Evaluating the Performance of the Pediatric Acute Lung Injury Consensus Conference Definitionof Acute Respiratory Distress Syndrome. Pediatr Crit Care Med 18(1): 17-25.

11. Dauger S, Le Bourgeois F, Guichoux J, Brissaud O (2017) Acute respiratory distress syndrome in childhood: Changing definition and news from the Pediatric Consensus Conference. Arch Pediatr 24(5): 492-498.

12. De Luca D, van Kaam AH, Tingay DG, Courtney SE, Danhaive O, et al. (2017) The Montreux definition of neonatal ARDS: Biological and clinical background behind the description of a new entity. Lancet Respir Med 5(8): 657-666.

13. Hammoud MS, Raghupathy R, Barakat N, Eltomi H, Elsori D (2017) Cytokine profiles at birth and the risk of developing severe respiratory distress and chronic lungdisease. J Res Med Sci 22: 62.

14. Aisiku IP, Yamal JM, Doshi P, Benoit JS, Gopinath S, et al. (2016) Plasma cytokines IL-6, IL-8, and IL-10 are associated with the development of acute respiratorydistress syndrome in patients with severe traumatic brain injury. Crit Care 20: 288.

15. Mei H, Zhang Y, Liu C, Zhang Y, Liu C, et al. (2018) Messenger RNA sequencing reveals similar mechanisms between neonatal and acute respiratory distress syndrome. Mol Med Rep 17(1): 59-70.

16. Wohlrab P, Kraft F, Tretter V, Ullrich R, Markstaller K, et al. (2018) Recent advances in understanding acute respiratory distress syndrome. F1000Res pii: F1000 Faculty Rev-263.

17. Mason G, Dooley N, Griffifiths M (2017) Acute respiratory distress syndrome. Clin Med 17(5): 439-443.

18. Dushianthan A, Cusack R, Goss V, Postle AD, Grocott MP (2012) Clinical review : Exogenous surfactant therapy for acute lung injury/acute respiratory distress syndrome-where do we go from here. Crit Care $16(6): 238$.

19. Kneyber MC, Jouvet PA, Rimensberger PC (2014) How to manage ventilation in pediatric acute respiratory distress syndrome? Intensive Care Med 40(12): 1924-1926.

20. Nadir Y, Thomas NJ (2016) Relevant outcomes in pediatric acute respiratory distress syndrome studies. Front Pediatr 4: 51.

21. Beitler JR, Schoenfeld DA, Thompson BT (2014) Preventing ARDS: progress, promise, and pitfalls. Chest 146(4): 1102-1113.

22. Bhattacharjee S, Soni KD, Maitra S (2018) Recruitment maneuver does not provide any mortality benefit over lung protective strategyventilation 
in adult patients with acute respiratory distress syndrome: A metaanalysis and systematic review of the randomized controlled trials. J Intensive Care 6: 35.

23. Thompson BT, Chambers RC, Liu KD (2017) Acute respiratory distress syndrome. N Engl J Med 377(6) : 562-572.

24. Ochiai R (2015) Mechanical ventilation of acute respiratory distress syndrome. J Intensive Care 3(1): 25.

25. Ward S, Quinn C, Valentine S, Sapru A, Curley MA, et al. (2016) Poor Adherence to Lung Protective Mechanical Ventilation in Pediatric Acute Respiratory Distress Syndrome. Pediatr Crit Care Med 17(10): 917-923.

26. Combes A, Fanelli V, Pham T, Ranieri VM (2019) Feasibility and safety of extracorporeal $\mathrm{CO} 2$ removal to enhance protective ventilation in acute respiratory distress syndrome: the SUPERNOVA study. Intensive Care Med 45(5): 592-600.

27. Schmidt M, Jaber S, Zogheib E, Godet T, Capellier G, et al. Feasibility and safety of low-flow extracorporeal $\mathrm{CO} 2$ removal managed with a renal replacement platform to enhance lung-protective ventilation of patients with mild-to-moderate ARDS. Critical Care 22(1): 1-8.

28. Morelli A, Del Sorbo L, Pesenti A, Ranieri VM, Fan E (2017) Extracorporeal carbon dioxide removal (ECCO2R) in patients with acute respiratory failure. Intensive Care Med 43(4): 519-530.

29. Das A, Haque M, Chikhani M, Cole O, Wang W, et al. (2017) Hemodynamic effects of lung recruitment maneuvers in acute respiratory distress syndrome. BMC Pulm Med 17(1): 34.

30. Goligher EC, Hodgson CL, Adhikari NKJ, Meade MO, Wunsch H, et al. (2017) Lung Recruitment Maneuvers for Adult Patients with Acute Respiratory Distress Syndrome. A Systematic Review and Meta-Analysis. Ann Am Thorac Soc 14(Supplement_4): S304-S311.

31. Cavalcanti AB, Suzumura EA, Laranjeira LN, Paisani DM, Damiani LP, et al. (2017) Effect of Lung Recruitment and Titrated Positive EndExpiratory Pressure (PEEP) vs Low PEEP on Mortality in Patients With Acute Respiratory Distress Syndrome: A Randomized Clinical Trial. JAMA 318(14): 1335-1435.

32. (2015) Pediatric Acute Lung Injury Consensus Conference Group. Pediatric acute respiratory distress syndrome: Consensus recommendations from the Pediatric Acute Lung Injury Consensus Conference. Pediatr Crit Care Med 16(5): 428-429.

33. Lemyre B, Laughon M, Bose C, Davis PG (2016) Early nasal intermittent positive pressure ventilation (NIPPV) versus early Nasal Continuous Positive Airway Pressure (NCPAP) for preterm infants. Cochrane Database Sys Rev, 2016, 12(12): D5384.

34. Li W, Long C, Zhangxue H, Jinning Z, Shifang T, et al. (2015) Nasa intermittent positive pressure ventilation versus nasal continuous positive airway pressure for preterm infants with respiratory distress syndrome : A meta-analysis and up-date. Pediatr Pulmonol 50(4): 402409.

35. Course C, Chakraborty M (2016) Respiratory support for preterm infants-the Cochrane evidence and beyond[J]. Paediatr Child Health, 2016, 26(4): 147-151.

36. Jia X, Yan C, Xu S, Gu X, Wan Q et al. (2018) Predictive factors for failure of non-invasive positive pressure ventilation in immunosuppressed patients with acute respiratory failure. Zhonghua wei zhong bing ji jiu yi xue 30(2): 107-111.

37. Meade MO, Young D, Hanna S, Zhou Q, Bachman TE, et al. (2017) Severity of Hypoxemia and Effect of High-Frequency Oscillatory Ventilation in Acute Respiratory Distress Syndrome. Am J Respir Crit Care Med 196(6): 727-733.

38. Guo YX, Wang ZN, Li YT, Pan L, Yang LF, et al. (2016) High-frequency oscillatory ventilation is an effective treatment for severe pediatric acute respiratory distress syndrome with refractory hypoxemia. Ther Clin Risk Manag 12: 1563-1571.
39. Bateman ST, Borasino S, Asaro LA, Cheifetz IM, Diane S, et al. (2016) Early High-Frequency Oscillatory Ventilation in Pediatric Acute Respiratory Failure. A Propensity Score Analysis. Am J Respir Crit Care Med 193(5): 495-503.

40. Praud JP, Fortin-Pellerin E (2017) Non-invasive high-frequency oscillatory ventilation for preterm newborns: The time has comefor consideration. Pediatr Pulmonol 52(12): 1526-1528.

41. El-Nawawy A, Moustafa A, Heshmat H, Abouahmed A (2017) High frequency oscillatory ventilation versus conventional mechanical ventilation in pediatricacute respiratory distress syndrome: A randomized controlled study. Turk J Pediatr 59(2): 130-143.

42. Qiao JY, Li YZ, Wang HY, Zhang SD (2017) A Meta-analysis of the efficacy of high-frequency oscillatory ventilation versus conventionalmechanical ventilation for treating pediatric acute respiratory distress syndrome. Zhongguo Dang Dai Er Ke Za Zhi 19(4): 430-435.

43. Munshi L, Del Sorbo L, Adhikari NKJ, Hodgson CL, Wunsch H, et al. (2017) Prone Position for Acute Respiratory Distress Syndrome. A Systematic Review and Meta-Analysis. Ann Am Thorac Soc 14(Supplement 4): S280-S288.

44. Setten M, Plotnikow GA, Accoce M (2016) Prone position in patients with acute respiratory distress syndrome. Rev Bras Ter Intensiva 28(4): 452-462.

45. Lupton-Smith A, Argent A, Rimensberger P, Frerichs I, Morrow B (2017) Prone Positioning Improves Ventilation Homogeneity in Children With Acute Respiratory Distress Syndrome. Pediatr Crit Care Med 18(5): e229-e234

46. Drahnak DM, Custer N (2015) Prone Positioning of Patients With Acute Respiratory Distress Syndrome. Crit Care Nurse 35(6): 29-37.

47. Cho YJ, Moon JY, Shin ES, Kim JH, Jung H, et al. (2016) Clinical Practice Guideline of Acute Respiratory Distress Syndrome. Tuberc Respir Dis (Seoul) 79(4): 214-233.

48. Barbaro RP, Boonstra PS, Moler FW, Davis MM, Prosser LA (2017) Hospital-level variation in inpatient cost among children receiving extracorporeal membraneoxygenation. Perfusion 32(7): 538-546.

49. Barbaro RP, Paden ML, Guner YS, Raman L, Ryerson LM, et al. (2017) Pediatric Extracorporeal Life Support Organization Registry International Report 2016[J]. ASAIO J 63(4): 456-463.

50. Dalton HJ, Macrae DJ (2015) Extracorporeal support in children with pediatric acute respiratory distress syndrome: Proceedings from the Pediatric Acute Lung Injury Consensus Conference. Pediatr Crit Care Med 16(5 Suppl 1): S111-s117.

51. Schaible T (2015) Extracorporeal membrane oxygenation in children. Med Klin Intensivmed Notfmed 110(6): 438-444.

52. Yan GF, Lu GP, Lu ZJ, Chen WM (2018) Application of extracorporeal membrane oxygenation in children with acute respiratory distress syndrome. Zhongguo Dang Dai Er Ke Za Zhi 20(9): 701-705.

53. Zhao Z, Hong XY, Liu YY, Zhang XJ, Bao LS, et al. (2018) Four cases of acute respiratory distress syndrome patients transported with venovenousextracorporeal membrane oxygenation. Zhonghua Er Ke Za Zhi 56(4): 298-302

54. Combes A,Pesenti A,Ranieri VM (2017) Fifty Years of Research in ARDS Is Extracorporeal Circulation the Future of Acute Respiratory Distress Syndrome Management? Am J Respir Crit Care Med 195(9): 1161-1170.

55. Kurihara C, Walter JM, Singer BD, Cajigas H, Shayan S, et al. (2018) Extracorporeal Membrane Oxygenation Can Successfully Support Patients With Severe AcuteRespiratory Distress Syndrome in Lieu of Mechanical Ventilation. Crit Care Med 46(11): e1070-e1073.

56. Barbaro RP, Xu Y, Borasino S, Truemper EJ, Watson RS, et al. (2018) Does Extracorporeal Membrane Oxygenation Improve Survival in Pediatric 
Acute Respiratory Failure? Am J Respir Crit Care Med 197(9): 11771186.

57. Mehrabadi A, Lisonkova S, Joseph KS (2016) Heterogeneity of respiratory distress syndrome: Risk factors and morbidity associated with early and late gestation disease. BMC Pregnancy Childbirth 16(1): 281.

58. Amigoni A, Pettenazzo A, Stritoni V, Circelli M (2017) Surfactants in Acute Respiratory Distress Syndrome in Infants and Children: Past, Present and Future. Clin Drug Investig 37(8): 729-736.

59. Echaide M, Autilio C, Arroyo R, Perez-Gil J (2017) Restoring pulmonary surfactant membranes and films at the respiratory surface. Biochim Biophys Acta Biomembr 1859(9 Pt B): 1725-1739.

60. Sweet DG, Carnielli V, Greisen G, Hallman M, Ozek E, et al. (2017) European consensus guidelines on management of respiratory distress syndrome-2016 update. Neonatology 111(2): 107-125.

61. Wang LP, Mao QH, Yang L (2017) Effect of pulmonary surfactant combined with mechanical ventilation on oxygenation functions and expressions of serum transforming growth factor-beta1 (TGF- $\beta 1$ ) and bone morphogenetic protein 7 (BMP-7) of neonatal respiratory distress syndrome. Eur Rev Med Pharmacol Sci 21(19): 4357-4361.

62. Willson DF, Thomas NJ, Tamburro R, Truemper E, Truwit J, et al. (2013) Pediatric calfactant in acute respiratory distress syndrome trial. Pediatr Crit Care Med 14(7): 657-665.

63. Valentine SL,Nadkarni VM,Curley MA (2015) Nonpulmonary treatments for pediatric acute respiratory distress syndrome: proceedings from the Pediatric Acute Lung Injury Consensus Conference. Pediatr Crit Care Med 16(5 Suppl 1): S73-S85.

64. Mehta NM, Bechard LJ, Zurakowski D, Duggan CP, Heyland DK (2015) Adequate enteral protein intake is inversely associated with 60-d mortality in critically ill children: A multicenter, prospective, cohort study. Am J Clin Nutr 102(1): 199-206.

65. Mehta NM, Bechard LJ, Cahill N, Wang M, Day A, et al. (2012) Nutritional practices and their relationship to clinical outcomes in critically il children-an international multicenter cohort study. Crit Care Med 40(7): 2204-2211

66. Wong JJ, Han WM, Sultana R, Loh TF, Lee JH (2017) Nutrition Delivery Affects Outcomes in Pediatric Acute Respiratory Distress Syndrome. JPEN J Parenter Enteral Nutr 41(6): 1007-1013.

67. Guo Y, Cheng J, Li Y (2018) Influence of enteral nutrition initiation timing on curative effect and prognosis of acute respiratory distress syndrome patients with mechanical ventilation. Zhonghua Wei Zhong Bing Ji Jiu Yi Xue 30(6): 573-577.

68. Sinitsky L, Walls D, Nadel S, Inwald DP (2015) Fluid overload at 48 hours is associated with respiratory morbidity but not mortality in a generalPICU: retrospective cohort study. Pediatr Crit Care Med 16(3): 205-209.

\section{ISSN: 2574-1241}

DOI: 10.26717/BJSTR.2019.22.003820

Mei Hua. Biomed J Sci \& Tech Res

This work is licensed under Creative

Commons Attribution 4.0 License

Submission Link: https://biomedres.us/submit-manuscript.php
69. Seguin J, Albright B, Vertullo L, Lai P, Dancea A, et al. (2014) Extent, risk factors, and outcome of fluid overload after pediatric heart surgery. Crit Care Med 42(12): 2591-2599.

70. Ingelse SA, Wösten-van Asperen RM, Lemson J, Daams JG, Bem RA, et al. (2016) Pediatric Acute Respiratory Distress Syndrome: Fluid Management in the PICU. Front Pediatr 4: 21.

71. Marts LT, Kempker JA, Martin GS (2017) Fluid Management in Acute Respiratory Distress Syndrome: Do We Have All the FACTTs to Determine the Effect of Race? Ann Am Thorac Soc 14(9): 1391-1392.

72. Silversides JA, Major E, Ferguson AJ, Mann EE, McAuley DF, et al. (2017) Conservative fluid management or deresuscitation for patients with sepsis or acute respiratory distress syndrome following the resuscitation phase of critical illness: A systematic review and meta-analysis. Intensive Care Med 43(2): 155-170.

73. Selewski DT, Cornell TT, Lombel RM, Blatt NB, Han YY, et al. (2011) Weight-based determination of fluid overload status and mortality in pediatric intensive care unitpatients requiring continuous renal replacement therapy. Intensive Care Med 37(7): 1166-1173.

74. Baranwal AK, Murthy AS, Singhi SC (2015) High-dose Oral Ambroxol for Early Treatment of Pulmonary Acute Respiratory Distress Syndrome: an Exploratory, Randomized, Controlled Pilot Trial. J Trop Pediatr 61(5): 339-350.

75. Wu X, Li S, Zhang J, Zhang Y, Han L, et al. (2014) Meta-analysis of high doses of ambroxol treatment for acute lung injury/acute respiratory distress syndrome based on randomized controlled trials. J Clin Pharmacol 54(11): 1199-1206.

76. Karam O, Gebistorf F, Wetterslev J, Afshari A (2017) The effect of inhaled nitric oxide in acute respiratory distress syndrome in children and adults: a Cochrane Systematic Review with trial sequential analysis. Anaesthesia 72(1): 106-117.

77. Dowell JC, Thomas NJ, Yehya N (2017) Association of Response to Inhaled Nitric Oxide and Duration of Mechanical Ventilation in Pediatric Acute Respiratory Distress Syndrome. Pediatr Crit Care Med 18(11): 1019-1026.

78. Monsalve-Naharro JÁ, Domingo-Chiva E, García Castillo S, CuestaMontero P, Jiménez-Vizuete JM (2017) Inhaled nitric oxide in adult patients with acute respiratory distress syndrome. Farm Hosp 41(2): 292-312.

79. Antebi B, Mohammadipoor A, Batchinsky AI, Cancio LC (2018) The promise of mesenchymal stem cell therapy for acute respiratory distress syndrome. J Trauma Acute Care Surg 84(1): 183-191.

80. Horie S, Gonzalez HE, Laffey JG, Masterson CH (2018) Cell therapy in acute respiratory distress syndrome. J Thorac Dis 10(9): 5607-5620.

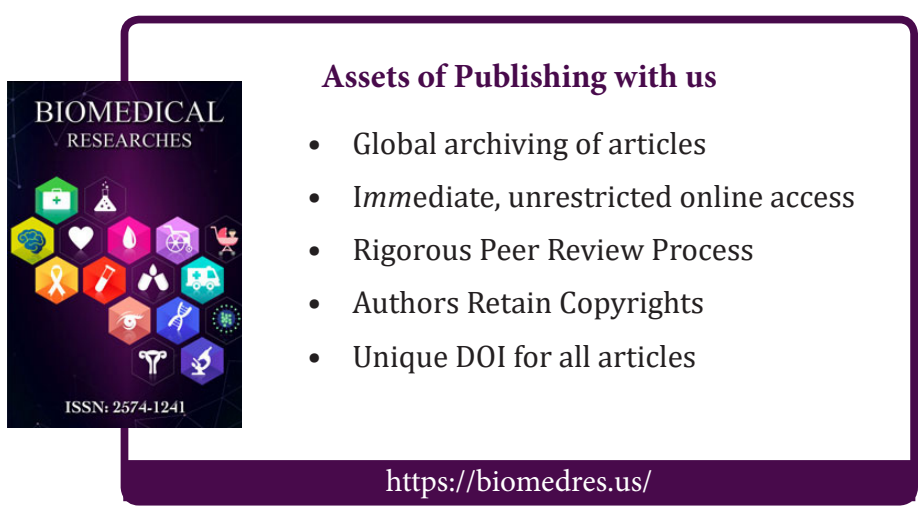

